\title{
Holiness without the holy One(s): Towards an 'evental' account of holiness
}

Author:
Jakub Urbaniak ${ }^{1}$
Affiliation:
'Department of Systematic
Theology, Faculty of
Theology, University of the
Free State, South Africa
Corresponding author:
Jakub Urbaniak,
jakub-urbaniak@hotmail.
com
Dates:
Received: 13 May 2016
Accepted: 29 Aug. 2016
Published: 14 Nov. 2016
code with your
How to cite this article:
Urbaniak, J., 2016, 'Holiness
without the holy One(s):
Towards and "evental"
account of holiness', HTS
Teologiese Studies/
Theological $72(4)$, a3485.
http://dx.doi.org/10.4102/
hts.v72i4.3485
Copyright:
Q 2016 . The Authors.
Licensee: AOSIS. This work
is licensed under the
Creative Commons
Attribution License.

Should holiness be conceived as a predicate (an attribute), a state (a mode of being) or an event (a process)? It can certainly be understood as God's primary attribute. This is how much of classical Christian theology sees it. It can also be thought of as a particular modus of existence shared by God and the holy ones (the saints and the angels), as attested by much of Christian tradition and popular imagination. A more dynamic view of holiness can be found in Scripture and throughout Christian theological tradition; and yet, in the modern era, it has been overshadowed by the first two tendencies. This article offers a tentative enquiry into an 'evental' account of holiness by drawing from (1) Niels Gregersen's and Elizabeth Johnson's reflection on 'deep incarnation' and 'deep resurrection' as well as (2) John B. Cobb's and Marjorie Suchocki's process theology of the Spirit. Firstly, the 'from above' approach to holiness, prevailing in modern Christian theology, is briefly discussed based on John Webster's understanding of holiness as God's personal moral relation to humanity. Secondly, I suggest an alternative 'from below' approach to holiness based on Gregersen's and Johnson's deep Christology. Thirdly, Cobb's and Suchocki's take on 'creative transformation' and Suchocki's original appropriation of Cobb's insights on process pneumatology are used as a hermeneutic key to reinterpret holiness as an 'evental' category. Finally, the notion of the holiness of life is reconsidered in light of my proposal.

You know, one often speaks of ethics to describe what I do, but what really interests me in the end is not ethics, not ethics alone, but the holy, the holiness of the holy. (Levinas in Derrida 1999:4; cf. also Levinas 2001:47; 49)

\section{Introduction}

This article seeks to explore a radically 'evental' account of holiness inspired by (1) Niels Gregersen's and Elizabeth Johnson's deep Christology as well as (2) John B. Cobb's and Marjorie Suchocki's process theology of the Spirit. My thesis is not simply that we can think about holiness as an event. Rather, I argue that if this is how God communicates God's own self to the community of life (in Jesus Christ and through the Spirit) and how God allows this community of life to participate in God's own life (in Jesus Christ and through the Spirit), then holiness is a process, something that happens, an event rather than an entity, a call rather than a cause, a promise rather than a presence (Caputo 2006:12-13).

Much of classical Christian theology has conceived of holiness as God's primary attribute. It can also be thought of as a particular state or mode of being shared by God and the holy ones (the saints and the angels), as attested by much of Christian tradition and popular imagination. A more dynamic view of holiness can be found in Scripture and throughout Christian theological tradition; and yet, in the modern era, it has been overshadowed by the first two tendencies. My aim will be to continue this hermeneutic trajectory by engaging theologically the resources of evolutionary biology and process thought.

I will begin by introducing the backdrop against which my proposal will be set. The 'from above' approach to holiness, prevailing in modern Christian theology, will be briefly discussed based on John Webster's understanding of holiness as God's personal moral relation to humanity. Secondly,

Note: Dr Jakub Urbaniak (PhD: UBO Brest; DTh/MTh: UAM Poznan) came to South Africa in 2010 from Poland. He is a research fellow at the Faculty of Theology, University of the Free State, and a Senior Lecturer in Systematic Theology and Philosophy of Religion at St Augustine College, a catholic university in Johannesburg. He is also an extraordinary lecturer a the his postdoctoral fellowship (2013-2014). His research over recent years has examined questions raised by global ecumenism with the focus on Hans Küng's theology of religions and global ethics. Recently, a number of encounters with Black, Feminist and Queer African theologians have served as a catalyst to his 'contextual turn'. He has engaged in particular with Tinyiko Maluleke's Christological approach His current research focuses on the category of 'life' as a hermeneutic key to bridging the gap between ecological theologies and contextual/liberation theologies, with their various social-political emphasis. 
I will suggest an alternative 'from below' approach to holiness based on Gregersen's and Johnson's eco-theological reflection on 'deep incarnation' and 'deep resurrection'. Thirdly, Cobb's and Suchocki's take on 'creative transformation' and Suchocki's original appropriation of Cobb's insights on process theology of the Spirit will be used as a hermeneutic key to reinterpret holiness in terms of event. Finally, the notion of the holiness of life will be reconsidered through the lens of my proposal.

Among many definitions of holiness available in the literature, let me single out a rather frivolous one by the Old Testament scholar John Rogerson who says, 'Holiness is a word in the English language whose meaning depends upon the contexts in which it is used and the interests of those who use it'. Indeed, the uses of the term are manifold: holy cities, holy books, holy days, holy cows, holy objects, holy spirits, holy persons and so on. Even within Christianity, the expression such as 'Holy Father' remains ambiguous, for while most Christians will be inclined to seek this 'Father' in heaven, some devout Catholics may choose to visit the Vatican City. Therefore, before considering the possibility of rethinking the Christian notion of holiness from below, one needs to make at least some basic terminological clarifications.

In this study, the departure point for my exploration of the notion of holiness will be its theological and, indeed, theocentric meaning. According to some scholars, holiness is the most theocentric concept in Scriptures, something that belongs totally, absolutely and unconditionally to God (cf. Waaijman 2002:320ff). This understanding is epitomised in the prophet Isaiah's words of praise: 'Holy, holy, holy is the Lord of hosts; the whole earth is full of his glory' $(6: 3){ }^{1}$ Holiness defines God in such an intimate way that it can be considered God's own name: God is the 'Holy One'. Thus, more than being merely one of God's characteristics, holiness, being holy, connotes who God is. My aim will be to reinterpret this radically theocentric view of holiness in light of Gregersen's and Johnson's christic paradigm and Cobb's and Suchocki's process pneumatology.

Even though in our daily language we often use the terms 'holy' and 'sacred' interchangeably, many scholars invoke the distinction between them. For instance, Max Scheler (1960:315-316) argues that the holy and the sacred connote two different realities. While holiness is an attribute of God, not of worldly things, sacred is a purely derivative term: 'anything which has been sanctified or consecrated from out of God's holiness is then described as sacred' (Zunic 2014:258). Emanuel Levinas goes even a step further as he treats holiness and the sacred as antithetical terms (Caruana 2006:562). Holiness is for Levinas equivalent to desacralisation, that is, the destruction of the sacred, and, as such, can act as an antidote to the experience of the sacred based on 'the ostensibly direct union with the supernatural that is sought after by those who partake of the sacred' (Caruana 2006:580). In this article, I do not follow any of the scholars who argue for a strict differentiation of the 1.All scripture references are quoted according to the NRSV Catholic Edition. terms 'holy' and 'sacred'. Instead, I use both of them in a more colloquial and thus broader sense.

I have no intention of redefining the notions of the holy and the sacred. Holiness is one of those key concepts that are in fact undefinable, in the sense that no single definition can exhaust their meaning. And yet I believe that, paradoxically, by struggling with its various quasi-definitions, we can somehow deepen and nuance our understanding of the meaning it conveys to us.

\section{Background: Thinking holiness from above}

In his 2003 book on Holiness, British theologian John Webster speaks of Christian theological thinking as 'an attempt at rational speech about the Holy One' (2003:99). Holiness is defined by Webster as 'God's personal moral relation to his [sic] creatures' (Webster 2003:100). However, we soon discover that in the strict sense he applies the term only to humanity, for holiness understood as a mode of relation can be explored only at two levels: the ecclesial and the individual:

The Triune Holy One is the one who establishes fellowship: as Father willing and forming the creature for fellowship, as Son defending that fellowship against the offensive of sin, and as Spirit bringing that fellowship to its human completion. (Webster 2003:100ff)

Webster sees a Christian theology of holiness as 'an exercise of holy reason' which is 'segregated by God so that God's communicative presence as Father, Son, and Spirit can be known and loved' (Webster 2003:99). Such theology reads the canon of the Scripture 'as a witness to God's self-promulgation, and is unpersuaded that much is to be gained from reading the canon as an expression of the experience of the holy-in-general' (Webster 2003:99). Hence, the urgent apologetic task of answering to a need for continual conversion of the church and the culture to the gospel of holiness (Webster 2003:105). In an interesting comment towards the end of his book, Webster posits that 'a crucial aspect of holiness is an increase in concentration: the focusing of will, mind and affections on the holy God and his [sic] ways with us' (Webster 2003:105).

Interestingly, James Arcadi, a young analytic theologian (thus coming from a distinctly different theological background than Webster), in his article on a theory of consecration, offers an understanding of holiness which, in essence, is not distant from the one developed by Webster:

I suggest that holiness can be construed as a specific relation of ownership that obtains between an object and God.

Consecrate to $=\mathrm{df}$ set apart an object for God's use.

This refinement also slightly alters the definition of holy.

Holy (adj.) = df a term used to describe an object that has been set apart for a Godly use. (Arcadi 2013:922-923)

Arcadi utilises the tools of contemporary philosophy of language to analyse the Biblical phenomenon of consecration. He explicates it as the separation of an object for God's use 
which occurs in a linguistic community and is for that linguistic community. Once an object undergoes consecration, that object becomes holy, that is, owned by God in a stronger sense than God's general ownership of the cosmos (Arcadi 2013:924).

My argument is that Webster's and Arcadi's accounts of holiness are representative of the typical 'from above' approach to holiness which dominated Christian theology in the modern era. Such an approach can be epitomised by the paradigmatic call from Leviticus 20:26: 'You shall be holy to me; for I the Lord am holy, and I have separated you from the other peoples to be mine'. ${ }^{2}$ And this notion of being 'separated' and 'set aside' indicates the classical Christian way of conceptualising holiness. In the words of Nikolaj Zunic:

Hagios, sanctus, holy: these words connote a reality which is separate and distinct from the normal everydayness of human existence. What is holy is contrasted with what is ordinary and common (koinos) (Pieper 1991:13-14). The holy is removed from the normal, customary mode of existence and it occupies its own unique dimension of being. Traditionally, the holy, in terms of the sacred, has been set apart from the profane which lies outside of the temple or sanctuary and does not partake in the sacred rituals of religious worship. (Zunic 2014:258)

Put simply, if we want to know what holiness is all about, we have to turn our eyes to the Holy One or, in some cases, to the holy Ones, the saints. Even the title of the recent conference of the Society for the Study of Christian Spirituality held at St Augustine College in Johannesburg confirms, to an extent, that tendency: 'Holiness: On the holy, the Holy One, sanctification and saints'. ${ }^{3}$ In Zunic's phrase, 'God alone is the primary analogate of all holiness. Objects in this world can be described as holy or sacred only' insofar as they remain 'in relation to the paradigm and source of all holiness in God' (Zunic 2014:258).

There is certain logic of 'chosenness' and, by implication, of exclusion, which underlies this 'from above' approach to holiness. By selecting and setting apart (that is, by 'sanctifying' or 'consecrating') God establishes sacred times, places, objects, people, events and so on. They are sacred in contrast to the rest of times, places, objects, events and so on, which are unholy or profane. Put somewhat simplistically, God chose Abram and made him Abraham; God chose Israel and, implicitly, not any other nation; God chose Mary, and not any other woman, to be the mother of the promised messiah and so on. This image of a choosing God may be exegetically justified and it has certainly played an important role in Christian theological tradition. However, is this the most radical understanding of the God who communicates Godself in Jesus Christ and through the Spirit of Life?

\section{Challenge: Thinking holiness from below}

I believe that Elizabeth Johnson, one of the leading feminist theologians of our day, invites us to take a different approach

2.See also Leviticus 11:44; 19:2. This Old Testament commandment is repeated in 1 Peter 1:16: 'You shall be holy, for I am holy'.

3.See The Bi-annual Meeting of the Society for the Study of Christian Spirituality, 20-24 May 2015. to holiness. It is definitely an approach 'from below' as Johnson consults ... the beasts, as advised by Job:

Ask the beasts, and they will teach you; the birds of the air, and they will tell you; ask the plants of the earth, and they will teach you; and the fish of the sea will declare to you. (Job 12:7-8)

Johnson's book Ask the Beasts: Darwin and the God of Love, published in 2014, is the fruit of a genuine 'dialogue between Darwin's view of evolution and Christian belief in the God of love' (2014:285). She is careful to distinguish scientific views about the theory of descent with modification from the so called 'social Darwinism'. Thus, her study offers valuable resources for a much needed theological engagement with the theory of evolution.

Johnson observes that biological evolution is a deeply relational process. 'That all species are related in the flow of life and death is a keystone of evolutionary theory', she writes (Johnson 2014:121). In the same vein, Moltmann states that 'the universe is not a monarchical pyramid, as Aristotle thought, but rather a covenanted, democratic community, consisting of living beings and environments' (2000:125). From the theological perspective, this web of relationships is precisely what God engages while communicating Godself to creation. Vatican II teaches that it pleased God to save us that is, to make us holy - not singly, but as a people ( $A G \S 2)$, indeed, as a community of creation. Today we understand much better than a few centuries ago the mechanisms through which 'mutual interplay has created the living world as we know it' (Johnson 2014:55). We know that 'animals and plants bound together by webs of complex relations' constitute 'a network of intricate interdependencies and mutual relations expressed in competition or profitable cooperation' (Johnson 2014:53-54). This is Darwin's 'gift to theology', as John Haught (2000:45) has audaciously claimed. Since we evolved relationally and since we exist symbiotically, 'our existence depends on interaction with the rest of the natural world' (Johnson 2014:196). As Johnson argues, in the face of our planet being in peril at our hands (WCC 1991:55):

theology as the study of God and all things in the light of God, has a vital contribution to make. By uncovering the importance of plants and animals and their ecosystems in their own relationship to God, such study can invigorate ethical behavior that cares for them with a passion integral to faith's passion for the living God. In the process, human beings find their own identity reimagined as vital members of the community of creation rather than as a species divorced from the rest, and step up to protect Earth's creatures as neighbors whom they love. (Johnson 2014:xvii)

Similar insights can be found in the recent encyclical by Pope Francis, Laudato Si': On Care for our Common Home. By paying attention to the manifestation of the Holy Mystery in nature, Francis says, 'we learn to see ourselves in relation to all other creatures: "I express myself in expressing the world; in my effort to decipher the sacredness of the world, I explore my own"' (LS §85) (Ricoeur 2009:216). In his Apostolic Exhortation Evangelii Gaudium, he writes, in turn, 'God has 
joined us so closely to the world around us that we can feel the desertification of the soil almost as a physical ailment, and the extinction of a species as a painful disfigurement' (EG §215).

This eco-theological perspective is in tune with a much broader, more dynamic and more inclusive way of understanding holiness in Christian tradition. Its roots can be found in the Bible; a number of theologians continue and articulate this trajectory masterfully in our day. For example, Elizabeth Johnson speaks of holiness in terms of the community of those - both living and dead, human and nonhuman alike - who are 'graced by the mystery at the heart of the universe' (2011:458).

However, for Johnson looking at God through the lens of biological evolution, asking the beasts does not imply downplaying references to Christian Revelation proper, namely Scripture-in-tradition. Rather, she enables the two perspectives to engage in a true dialogue. How? Among other ways, by an evolutionary reading of revelation and a Christological reading of evolution.

\section{Jesus of Nazareth: If thus is God, then where is the Holy One ${ }^{4}$}

The notion of 'deep incarnation' has been coined by Niels Gregersen and creatively elaborated upon by other theologians like Elizabeth Johnson and Jürgen Moltmann, to mention only a couple. John's Prologue lies at the centre of this Christological proposal:

For the concept of deep incarnation it is important that the divine Logos became sarx (Jn 1:14): not just as a human being (anthropos) as opposed to other species, and not just as an individual man (anēr) as opposed to being a woman. It was as flesh that the divine Logos 'lived' or 'dwelled' among us (Jn 1:14). The flesh is not only the principle of individualisation (as in Aristotle and Thomas Aquinas) but also the principle of sharing, namely sharing a bodily existence, based on a common physical matrix and living under similar biological conditions. (Gregersen 2013:260)

Johnson adapts a Christological expression from Gregersen: 'If this is God, then thus is God'. If Jesus is God-with-us, then his life, death and life again 'carry a precious disclosure about how incomprehensible holy Mystery, whom no one has seen or can see, relates to the world' (Johnson 2014:199). Deep incarnation signifies the:

radical divine reach through human flesh all the way down into the very tissue of biological existence with its growth and decay, joined with the wider processes of evolving nature that beget and sustain life. (Johnson 2014:196)

A radical embodiment presupposed by deep incarnation can be also read through the lens of the old patristic axiom: 'What is not assumed cannot be healed'. For centuries this soteriological principle has been interpreted almost exclusively in an anthropocentric manner, even though the

4.In the following section, I draw from my article, co-authored with Elijah Otu, on 'How to Expect God's Reign to Come: From Jesus' through the Ecclesial to the Cosmic Body' (Urbaniak \& Otu 2016). church Fathers had already developed a profound cosmic Christology. ${ }^{5}$ In our day, ecological theology widens this anthropocentric focus to include biocentric and cosmocentric dimensions (Johnson 2014:223, 2015:133). Gregersen, for instance, speaks of Christ as the incarnate One who has immersed 'himself into the grains of creation and into the biological conditions' shared by humankind with other lifeforms (2013:253-254). Johnson, in turn, views Jesus as God's Word or Wisdom (Sophia) who 'entered into solidarity with the entire biophysical world of which human beings are a part and on which their existence depends' (2015:140).

This has formidable ramifications not only for the creation but also for God's own self (which is never really only God's own). For in the Christ-event - from cave to cross and resurrection - God has entered 'into the sphere of the materially vulnerable and mortal to shed light on all from within' (Johnson 2015:134), but at the same time the entire matrix of materiality has been assumed in Jesus' body and blood, and thus into God's own life (Gregersen 2013:252). It is Logos made sarx that Paul has in mind when he says, 'In him the whole fullness of deity dwells bodily' (Col. 2:9). In the same vein, Rahner states that 'the climax of salvation history is ... taking on of matter so that it itself becomes a permanent reality of God' (1982:160).

In analogy to Gregersen's deep incarnation, Johnson suggests the notion of 'deep resurrection' as a way of pushing personal and even historical eschatologies beyond their human scope 'to include a blessed future for the whole natural world' (Johnson 2015:148; cf. also Johnson 2014:208-213). Deep incarnation is thus continued in the deep resurrection of the social and cosmic body into God's Trinitarian life (Gregersen 2013:260). In this context, Welker speaks of a 'spiritual body' (Pauline soma in contrast to sarx) which expresses both continuity and discontinuity between the mortal flesh dominated by non-divine powers and the immortal flesh mysteriously transformed by divine grace in the resurrection (Welker 2014:359-360).

Deep resurrection thus understood also implies the reinterpretation of the Jewish symbol of God's reign central to Jesus' preaching and deeds. In its ultimate eschatological sense, this symbol evokes, as Johnson reminds, of 'the moment when God finally triumphs over the powers of evil and the divine will is done on earth as it is in heaven' (Johnson 2015:144). From the perspective of deep resurrection, it becomes clear that 'the coming reign of God will effect nothing less than redemption and the end of sin, suffering, and death in favour of flourishing of all creatures' (2015:144). The incarnation is not merely a passing episode in God's involvement with the world of creation. Rather, incarnation must be seen as a perpetual reality, for - once Logos has become sar - 'there shall be neither separation nor confusion between Christ and creation' (Gregersen 2013:260-261). As the ultimate divine purpose, God's reign 'gives order and direction to the world - not just to a slice of the world, but to the whole world in its evolutionary history' (Johnson 2015:144).

5.For instance, Ambrose of Milan boldly preached that 'In Christ's resurrection the earth itself arose' (Patrologia Latina 16: 1354). 
In the same vein, Moltmann observes (2015:123):

The resurrection of Christ has to be grasped not only in the framework of a historical eschatology, but in cosmic eschatology too. The risen Christ is not just a hope for eternal life given to mortal human beings; he is also the future of all things in a 'new heavens and new earth, where righteousness is at home'. (2 Pt. 3:13)

Gregersen (2014:343) points out that in the first centuries of the Common Era, Christians departed from the Stoics in their insistence on the pre-material status of the divine Logos for the sake of retaining a Jewish and Platonic sense of God's transcendence. This is when the notions of logos asarkos (a 'fleshless Logos') and logos ensarkos (an 'enfleshed Logos') were coined, wherein one existed before the other. ${ }^{6}$ As a consequence, later theology has had a tendency to conceive of God's life in terms of temporal sequences, 'as if there existed three separate stages in the "nature" of Jesus Christ (preexistence, incarnation, and exaltation)' (Gregersen 2013: 256). In contrast to such a static and purely interventionist view of God's engagement with God's own creation, Johnson suggests to take as a point of departure 'a Trinitarian understanding of God who exists eternally in a perichoresis of mutual relations' (Johnson 2015:133-134). She writes:

In such a relational theology of God, it is precisely not the case that the transcendent Holy One enters the world for the first time in the historical person of Jesus Christ. Rather the Triune God is pervasively present as self-communicating Love throughout the cosmos from the beginning of time to the end. (Johnson 2015:134)

Thus, the divine Logos is present not only locally, in the particular body of Jesus, but also universally, as Creator and as Redeemer, at the very core of material existence (Gregersen 2014:344). According to such a co-terminous logic, God is actively creating 'within, through, and under the guise of material processes' (2014:325). To unpack this statement in Trinitarian terms, Gregersen refers to Logos as the 'informational principle' and to Spirit as the 'energising principle' (2014:325). 'It is only in the interplay between information (Logos) and energy (Spirit)', he points out, 'that the world of creation produces evolutionary novelties rather than mere repetitions' (2014:325; cf. also Gregersen \& Görman 2007:307-314). While some of the aspects of this creative activity have a rather strong law-like character, others rely on more contingent historical processes (Gregersen 2014:345).

In light of this 'deep Christology', ${ }^{7}$ one has to pose the question which will prove central to our enquiry: If thus is God, then where is the Holy One? If God communicates God's own self to the world through the process of evolution which includes both law-like regularities and randomness ... If chance is indeed, as Peacocke suggests, a tool that allows matter to explore the full range of its possibilities (Peacocke 1993:117) ... If natural systems have indeed certain freedom

6.At the same time, as Gregersen notes (2014:343), the early Christian writers balanced this 'Platonising' element with a strong 'Stoicising' doctrine of the incarnation of the Logos: 'Logos became flesh (sarx)' (Jn. 1:14).

7.This term used by Elizabeth Johnson seems to encompass her reflection on deep incarnation, deep resurrection, deep ministry, as well as christic paradigm (Johnson 2015) to explore and discover themselves within a context of lawlike regularities, which is, as some scientists claim, 'one of the natural conditions for the possibility of the emergence of free and conscious human beings as part of the evolving universe' (Johnson 2014:172) ... If, finally, the evolving world operates without compulsion, according to its own dynamics, working freely, in concursus with the incomprehensible God who brings forth the fullness of the community of life (Johnson $2014: 160,164)$... If all that is true, this means, as Johnson asserts, that 'God's act is not a discrete ingredient that can be isolated and identified as a finite constituent of the world. In this sense, the world necessarily hides divine action from us' (Johnson 2014:164; author's italics). Where is the Holy One to be found in such a world? Here and there? Or rather everywhere and nowhere?

\section{Holiness as 'creative transformation'}

In her book on God, Christ, Church: A Practical Guide to Process Theology (1982), Marjorie Suchocki points out that 'without a wider frame of reference provided by philosophy, theological statements run the risk of being based only on the needs which they address' (Suchocki 1982:45). Aware of that risk, I now turn to process thought, a philosophical and theological tradition based on the metaphysical system of Alfred Whitehead, in the search of 'a wider frame of reference' for the 'evental' account of holiness:

In giving up the concept of unchanging substance process philosophy and theology avoid the concept of divine immutability that came with this substance metaphysics. Like the God of revealed religions the process God is dynamic, everchanging, taking in new experience as the universe grows and develops in creative transformation. (Gier 1994; author's italics) ${ }^{8}$

By talking about creative transformation, John Cobb Jr. means 'a certain type of change and growth that occurs as a result of God's introduction of novelty' (McDaniel \& Bowman 2006:162); a 'way change occurs rather than the specific content at any given time' (Cobb 1991:97). ${ }^{9}$ Creative transformation is 'the call forward' which 'breaks the bonds of determinism and introduces new possibilities into the world' (McDaniel \& Bowman 2006:162; cf. also Cobb 1998:49-50). Creative transformation is a change that 'emerges from grasping that which the past alone does not suggest. It surprises us, it amazes us' (McDaniel \& Bowman 2006:165). As a positive change for the new, creative transformation has four characteristics; they are: (1) contextual and particular, (2) challenging, (3) noncoercive and (4) universal (McDaniel \& Bowman 2006:162).

Cobb explicitly links creative transformation with a Logos Christology, wherein Logos is the source of novelty in each moment. In Suchocki's phrase:

8.The process dipolar concept provides for a dynamic, changing aspect of God (Whitehead's 'consequent nature') and a formal, unchanging aspect (Whitehead's 'primordial nature' [PN]). As the 'mind' of God, the PN contains the formal principles ('eternal objects') that allow for order and structure in the universe (Gier 1994).

9.Cobb was not the first one to write about creative transformation. Pierre Teilhard de Chardin, independently of Whitehead, described a process of creative transformation that occurs in the world (de Chardin 1971:21-24). The notion appears also in Henry N. Wieman's The Source of Human Good (1946). Cobb appears also in Henry N. Wieman's The Source of Human Good (1946). Cobb
acknowledges his indebtedness and departure from Teilhard and Wieman (Cobb 1998:51-57). 
Jesus of Nazareth becomes the one in history who fully constitutes himself through this initial aim of God, thus becoming the manifestation of God's peace in history. The abstract technical notion of God is clothed with the historical form of love, leading to hope. Jesus is the Christ in history, and Christ is the image of creative transformation. (Suchocki 1997:178)

Where incarnate Logos - that is, Christ - is effectively present, 'there is creative transformation' (Cobb \& Griffin 1976:100). This often challenges the status quo, as it is currently experienced:

The Logos is threatening to any given world, for it functions to transcend and transform it ... The function of Logos is to introduce tension between what has been and what might be and continuously to challenge and upset the established order for the sake of the new. (Cobb \& Griffin 1976:84)

The efficacy of creative transformation, when it comes to humanity, lies ultimately in a free decision (Cobb 1988:144). The full change may occur only when God's aims are freely accepted and incorporated. Far from being a law, it is an offering to the world (Cobb 1991:116). But creative transformation is not limited to human life; rather, it has a universal quality to it - it is everywhere and in everything (McDaniel \& Bowman 2006:163). Under the influence of his readings in biology, evolution and ecological justice, Cobb expanded creative transformation to non-human life, eventually identifying it with life itself: 'Creative transformation ... is also the life in all living things.... As the immanence of God in the world, [it] is not only the way but life itself, the life by which all that is alive lives' (Cobb 1988:144; my italics). The identifying of creative transformation with life itself has far-reaching ethical and eschatological ramifications. Creative transformation, as far as human response to God's invitation is concerned, has a potential to liberate humanity and the planet from forces of death (McDaniel \& Bowman 2006:163):

Christ must be the life that struggles against the death-dealing powers that threaten us and the way that leads through the chaos of personal and global life to just, participatory, and sustainable society in which personal wholeness is possible. (Cobb 1988:143)

Elaborating on Cobb's views, Marjorie Suchocki, who identifies both as a process theologian and an ecofeminist theologian, points to the practical implications of creative transformation in the world: 'implications for how we build our cities, how we engage in deepening human community through interreligious dialogue, and how we can foster hope within a desperate world' (Suchocki 1997:177-178).

Suchocki also stresses that a creative transformation of the past always draws the world towards 'wider forms of inclusiveness' (1997:178), that is, ultimately, towards peace, which is the aim of all creative transformation. The particular form of peace is 'governed by inclusiveness of well-being' (1997:178):

... those who identify themselves with Christ become open to the risk of an identity radically informed not only by their own personal and cultural past, but also by the past and the future of others and, hence, toward the creation of more diverse modes of community that include the good of others as well as the self. This open identity is not restricted to the human scene; it includes an empathic association with the well-being of the whole created order. This openness of identity is itself the impulse toward acting for inclusive forms of the good, or peace. (Suchocki 1997:178)

The only way God can give us the possibilities which can lead to our creative transformation, Suchocki further observes, is by knowing us 'from the inside out as well as from the outside in' (1982:110). God knows all reality just as it knows itself. For instance, God knows that it is raining in Chicago not

by feeling it, but through the reality of the drops of moisture as they fall and through the experience of wetness as the drops touch the earth ... Every actuality that comes into existence is felt in its entirety, as it felt itself, by God. (Suchocki 1982:73)

What Illtyd Trethowan, a critic of process theology, calls 'panpsychism with a vengeance' (1985:96) has grave theological implications:

If God is in Jesus then God reveals through him that every sin is a sin felt by God and is therefore a sin against God, every pain is felt by God, and is therefore God's pain. The dreadful truth revealed in the crucifixion of Jesus Christ is that the world crucifies God. (Suchocki 1982:109-110)

Against such a backdrop, can we conceive of holiness in terms of constructive transformation? Rather than being abstractly attributed to the divine being, holiness would be seen as organically connected with the presence of incarnate Logos, of Jesus Christ. The previous section on deep incarnation made it clear that this presence cannot be restricted to sacred places, objects, times, beings and so on. For 'Jesus of Nazareth, was composed of star stuff and earth stuff; his life formed a genuine part of the historical and biological community of Earth' (Johnson 2014:209), and, as such, it has become the integral part of God's own life (which is never really only God's own). In Rahner's felicitous phrase, 'the climax of salvation history is ... taking on of matter so that it itself becomes a permanent reality of God' (1982:160). Because the whole world is touched by God, each and every portion of reality can become holy and thereby 'call us forward' by mediating God's presence to us (Suchocki 1982:68).

Another stark difference regarding holiness understood in terms of creative transformation is that it draws the created world towards ever wider forms of inclusiveness. Unlike traditional concept of holiness whose 'crucial aspect is an increase in concentration' (Webster 2003:105), or as Levinas has it, becoming 'aware of one's self as a separate and finite being' (Caruana 2006:580), in this new perspective, holiness is to be seen as a positive process aimed, not at separation and division, but at peace - a better future for all. Contextual and particular, challenging, non-coercive and universal, holiness appears as a 'happening' of God's presence at the very core of creation, as 'the life by which all that is alive lives' (Cobb 1988:144). 


\section{Event of holiness: Spirit proceeding from God and from the world}

In a process universe, everything affects everything else (Suchocki 1982:149). A similar view of reality emerges from Pope Francis' Laudato Si'; the phrase 'everything is interconnected' recurs in the encyclical three times (§70; §138; $\S 240)$ :

It cannot be emphasised enough how everything is interconnected. Time and space are not independent of one another, and not even atoms or subatomic particles can be considered in isolation. Just as the different aspects of the planet - physical, chemical and biological - are interrelated, so too living species are part of a network which we will never fully explore and understand. A good part of our genetic code is shared by many living beings. (LS §138)

Of course, classical theism, which traditionally insists on God's immutability, is very sceptical, to say the least, about process theology's view of the relationship between God and the world, wherein not only God affects the world but also vice versa (Morley [no date]). ${ }^{10}$ Nonetheless, one can find traces, albeit implicit, of a panentheistic view in Francis' document when he says that 'the universe unfolds in God, who fills it completely' (LS §233) and yet, at another place, that 'the things of this world ... do not possess [God's] fullness' (LS §88). That the world is infused with God's presence, both traditional and process theologians agree upon. The controversy concerns God's separateness from the world, what in theological and religious language tends to be described precisely in terms of God's holiness. Trethowan seems to refer to that very aspect of process doctrine of God when he interrogates:

God's life, in that account, consists only in organising possibilities of unity, beauty and holiness, and contemplating the results ... Has God, apart from the world and what he [sic] does with it, no life of his own? (Trethowan 1985:102)

The radical answer of process theologians is, 'No, God has no life that would be only God's own, for in Jesus Christ and through the Spirit, God makes the life of the community of creation God's own life; indeed, in Jesus Christ and through the Spirit, the community of life becomes a permanent reality of God'.

In this context, interconnectedness is being redefined and elevated to the rank of God's self-defining principle. Within the traditional metaphysical framework, the very notion of interconnectedness implies the primacy of the existence of various poles, actors or subjects. From a process perspective, on the contrary, it is an interconnectedness which comes first and which transcends, subverts and transforms all the ontotheological orders of being created - and imposed onto reality - by the human mind. Thus, reality is seen as a process

10.I refer to 'classical theism' in the broad sense, as a philosophical-theological approach to God that has prevailed in the history of Western thought and religion. It can be found ' $n$ the Greeks since Plato, in the Judaism of Philo, Maimonides, and others, in Christian orthodoxy generally, and in Islam as early as al-Kindi' (Morley n.d.). Generally in classical theism, God is conceived of as the most perfect possible being with a number of specific attributes such as incorporeality, simplicity, unity, eternity, immutability, impassibility, omnipotence, omniscience and omnibenevolence (Morley n.d.). that is modelled, shaped and driven by 'dynamics' that lie beyond and behind any being (or entity) as well as beyond and behind the totality of beings (or entities). Interconnectedness of everything is what renders holiness possible. Holiness happens always in-between, never within or without.

Robert Emmons and Cheryl Crumpler express a reverse concern which stems, nonetheless, from the same misunderstanding:

Almost any facet of life can become sacralised through a process of sanctification. This being the case, where does one draw the boundaries around the concept of sanctification? (Emmons \& Crumpler 1999:18)

Needless to say, no such boundaries may be drawn as far as holiness is conceived of as an event. Suchocki's creative interpretation of Cobb's theology of the Holy Spirit may shed more light on that view.

In his book Is It Too Late: A Theology of Ecology (1972), Cobb points out that the power of hope

is not to be found somewhere outside the organisms in which it is at work, but it is not to be identified with them either. We can conceive it best as Spirit. It is the belief in this Spirit, the giver of life and love, that is the basis of hope. In spite of all the destructive forces [we] let loose against life on this planet, the Spirit of Life is at work in ever new and unforeseeable ways, countering and circumventing the obstacles [we] put in its path. (Cobb 1972:143-144)

Like the dove symbolically replaced by the Hospital of the Holy Spirit in Florence, on Giotto's painting of the angelic annunciation to Mary (Suchocki 1997:181-182), cooperation with the Spirit of Life, according to Suchocki, also has to become incarnate in the concrete works of mercy. ${ }^{11}$ Like in classical Eastern theology, where the Spirit proceeds 'from the Father through the Son', so in this process formulation:

the Spirit derives from the aim from God's own nature mediated to us through the Christ. Insofar as we instantiate that aim, the Spirit is born in us, becoming one with us in the creation of community. (Suchocki 1997:184)

It has been said earlier that the world hides divine action from us. Now, the same truth can be expressed in pneumatological terms. The Spirit of Life is never manifest as Spirit per se; there is no direct identification of the Spirit but only the indirect witness to the Spirit's presence in the midst of the community of life through acts of creative transformation such as:

openness toward one another involving our deepest identity in interfaith or ecumenical dialogue; open and concerned action for the well-being of the whole of this earth; empathic identification with others, so that their future good is as important as our own; and a will to move toward yet ever more complex modes of community. (Suchocki 1997:184)

In what is perhaps the most critical aspect of her proposal, Suchocki posits that if the consequent nature be named as 11.Analogically, theology of the Spirit 'requires implicit portrayal through works directed toward the good - the peace - of the world' (Suchocki 1997:182). 
analogous to the Christian naming of Spirit, then the Spirit can no longer be understood to proceed from within God alone. Rather, Spirit everlastingly proceeds from God and the world' (Suchocki 1997:185; author's italics), from in-between God and the world, one may say. Thus, Spirit is what combines God and the world, what mutually correlates them. Spirit's manifestation is the work of the world as well as of God: while God offers the aim, the occasion in the world actualises it. 'God proposes, the world disposes ... Through the Spirit and in the Spirit, the world is introduced into God' (1997:185).

It is only a logical step for process theologians to identify the Spirit with creative transformation: 'Christ offers creative transformation; the Spirit is creative transformation realised in the world' (Suchocki 1997:184). To state that the universe as such is holy will not do justice to the dynamic mode of God's engagement with the created order; neither will stating that only God, and what God sanctifies, is holy. Since mutuality is the irrevocable mark of a process universe, the Spirit as the ultimate name of the event of holiness can only be seen as something that happens between God and the world. If the world is immanent in God as Spirit, then God is 'many and one at the same time' (1997:188):

The unity of this multiplicity follows from the work of the Spirit, born from God in the world and yet again in God, conforming the world to God. The conforming work is partial in the world, but would be complete in God, governed by God's own free subjective aim. (Suchocki 1997:188)

Insofar as the world incarnates God's purposes, the event of holiness occurs in the world, Spirit is born in the midst of the community of life. Received into the divine character, this Spirit of Life born out of flesh, through works of mercy, everlastingly completes the divine being through the redemption of the world. Thus happens the process of the creative transformation of reality (Suchocki 1997:189). To paraphrase Irenaeus's famous adage: The holiness of God is universe fully alive. ${ }^{12}$

\section{'I am the God of the living': Holiness of life reconsidered}

To close the loop, one must ask what meaning this 'evental' account of holiness has for a 'lived holiness' of those who desire to incarnate God's purposes in and through their lives. At least from a linguistic point of view, the suggestion to speak of holiness in terms of event or process is cumbersome, to say the least. So why to go through the effort of reinterpreting holiness? This somewhat odd postulate is driven by more than merely a willingness to free our language about holiness from onto-theological trappings. If we look at our own selves from the perspective of our biological identity, assumed to the core by Jesus Christ and brought by him into communion with the loving power of 'the God of life', we realise that, instead of being distant from what is holy, the natural world - including us, as an integral part of it - 'bears the mark of the sacred, being itself imbued with a spiritual presence' (Johnson 2014:150). Put bluntly, asking 'Who is the holy one?' or 'Who are the holy ones?' misses the very point of God's loving encounter with the world. If through the Christ-event life's centre of gravity comes to reside in life itself (Badiou 2003:62), a more adequate question would be 'What does foster life's holiness and what hinders it'?

I would like to suggest that the organic connection between holiness and life is what makes my proposal relevant and meaningful in both an existential and ethical sense. When Jesus speaks of his Father as 'God not of the dead, but of the living' (Mk 12:27; Mt 22:32), perhaps he pronounces the most intimate and proper name of God. Based on my proposal, it would make sense to say that God's holiness abides insofar as Life flourishes by which all that is alive lives (Cobb 1988:144). This Life can be called the incarnate Logos, Christ, when it is offered to the world as creative transformation; it can be called the Spirit when creative transformation is realised in the world (Suchocki 1997:184). Whether this Life flourishes never depends only on God or only on the community of creatures. Nothing but the synergy of the two can make it flourish, or what traditional theology calls 'cooperation with grace'.

One should not forget, however, that our reflection on life does not happen in a vacuum. Today the world faces the dilemma that could be aptly described in the words from Deuteronomy 30:19: 'I have set before you life and death, blessings and curses. Choose life so that you and your descendants may live ...'. As Suchocki points out:

the vulnerability of interdependence (of all life) can lead to planetary death as well as to richer forms of complexity. Process is not necessarily progress, and freedom allows the creative lure toward novelty to be perverted toward destructive ends. (Suchocki 1997:177)

In his Is it too late? A theology of ecology, Cobb's theologising has taken on a new urgency as he realised that theology can no longer be reduced to critical reflection upon one's faith for the sake of finding its contemporary forms. Indeed, in a milieu in which 'the survival of life itself may be at stake' (Cobb 1972:11), a new prophetic 'theology of life' is in demand.

One of the central questions that such theology has to engage is whether life is sacred and, if so, what are the implications of the holiness of life. Too often, religious discourse reduces the question of the sacredness of life to the issue of practical concerns about terminating life. Thus, engaging in conversation with secular authors can help theologians articulate their own broader frame of reference for addressing this question.

For non-religious thinkers like Suzanne Uniacke, the challenge posed by this question is whether there is a plausible secular near-analogue of 'holy' that is applicable to life (Uniacke 2004:65). As a way of clarification, Kleinig (1991:29) introduces two contrasts that indicate two basic understandings of life: life contrasts with death; and the 
living, the animate, also contrasts with the non-living, the inanimate. Biological life, 'a weird and exceedingly special state of matter' (Davies 2003), can be seen as a kind of 'primary material good' (Kohl 2001 quoted in Uniacke 2004:70). Kleinig locates the purported intrinsic value of biological life in its three inherent features, namely its selfintegrating and self-renewing character, and its dynamic interaction with environment (Uniacke 2004:78):

There is manifest in living organisms a distinctive independence of their environment that may evoke our affirmation and regard. By virtue of their self-integrating and self-renewing character, living organisms actively maintain their identity in a world that is constantly impinging upon them. (Kleinig 1991:171)

Ronald Dworkin opposes the view that the sacred character of life consists in life's 'near-miraculous' self-sustaining and adaptive properties (Dworkin 2004:142). His own discussion about the sacredness of biological life in Life's Dominion focuses, in turn, on a two-fold 'investment':

All life represents or embodies natural investment as the product of evolutionary creation.... Human lives also represent and embody the creative human investment of the subject of the life and of others. (Uniacke 2004:71-72)

These are merely samples of questions that appear on the horizon of theological enquiry once life's holiness is being pondered from the perspective suggested in this article. There are a number of other issues brought about by my proposal of an 'evental' account of holiness which could not be discussed here. One of them is the question about the place and understanding of grace, and the adequate language to articulate it, within an evolutionary-process framework.

\section{Conclusion}

This article argued that holiness is something that happens through the bond between the God of life and the community of life. This bond is life-giving in an ultimate eschatological sense because of the Spirit who, as the 'energising principle', is pervasively present and active throughout the cosmos from the beginning of time to the end (Johnson 2014:325, 2015:134). Let me close with the captivating words of Elizabeth Johnson:

The Spirit continually calls [the world] forth to a fresh and unexpected future ... It is as if at the Big Bang the Spirit gave the natural world a push saying, 'Go, have an adventure, see what you can become. And I will be with you every step of the way'. (Johnson 2014:156)

\section{Acknowledgements}

I am deeply grateful to my colleague and friend, Dr Judith Coyle, IHM, whose all-embracing and life-giving approach to Christian spirituality continues to inspire me, both in my life and in my research.

\section{Competing interests}

The author declares that he has no financial or personal relationships which may have inappropriately influenced him in writing this article.

\section{References}

Arcadi, J.M., 2013, 'A theory of consecration: A philosophical exposition of a Biblical phenomenon', The Heythrop Journal 54(6), 913-925. http://dx.doi.org/10.1111/ heyj.12040

Badiou, A., 2003, Saint Paul: The foundation of universalism, transl. R. Brassier, Stanford University Press, Stanford, CA.

Caputo, J.D., 2006, The weakness of God: A theology of the event, Indiana University Press, Bloomington, IL.

Caruana, J., 2006, "'Not ethics, not ethics alone, but the holy": Levinas on ethics and holiness', Journal of Religious Ethics 34(4), 561-583. http://dx.doi. org/10.1111/j.1467-9795.2006.00285.x

Cobb, J.B., 1972, Is it too late: A theology of ecology, Bruce, Beverly Hills, CA.

Cobb, J.B., 1988, 'Christ beyond creative transformation', in S.T. Davis (ed.), Encountering Jesus: A debate on Christology, pp. 141-178, John Knox Press, Atlanta, GA.

Cobb, J.B., 1991, Can Christ become good news again? Chalice Press, St. Louis, MO.

Cobb, J.B, 1998, God and the world, Wipf and Stock Publishers, Eugene, OR.

Cobb, J.B. \& Griffin, D.R. (eds.), 1976, Process theology: An introductory exposition, Westminster Press, Philadelphia, PA.

Davies, P., 2003, 'Is anyone out there?', The Guardian, 22 January, viewed 22 Apri 2016, from https://www.theguardian.com/education/2003/jan/22/ highereducation.uk

De Chardin, P.T., 1971, Christianity and evolution, Collins, London.

Derrida, J., 1999, Adieu: To Emmanuel Levinas, transl. P.-A. Brault \& M. Naas, Stanford University Press, Stanford, CA.

Dworkin, R., 2004, 'The concept of the sacred', in B. Rogers (ed.), Is nothing sacred?, pp. 59-80, Routledge, London.

Emmons, R.A. \& Crumpler, C.A., 1999, 'Religion and spirituality? The roles of sanctification and the concept of 'God', The International Journal for the Psychology of Religion 9(1), 17-24. http://dx.doi.org/10.1207/ s15327582ijpr0901_3

Gier, N.F., 1994, Theology bluebook, University of Idaho, Moscow, ID, viewed 22 April 2016, from http://www.webpages.uidaho.edu/ngier/process.htm

Gregersen, N.H., 2013, 'Deep incarnation and kenosis: In, with, under, and as: A response to Ted Peters', Dialog: A Journal of Theology 52(3), 251-262.

Gregersen, N.H., 2014, 'God, matter, and information: Towards a Stoicizing Logos Christology', in P. Davies \& N.H. Gregersen (eds.), Information and the nature of reality: From physics to metaphysics, pp. 319-348, Cambridge University Press, reality: From
Cambridge.

Gregersen, N.H. \& Görman, U. (eds.), 2007, Design and disorder: Perspectives from science and theology, International Society for Science and Religion, Cambridge.

Haught, J., 2000, God after Darwin: A theology of evolution, Westview Press, Boulder, CO.

Johnson, E.A., 2011, 'Communion of saints and Mary', in F. Schüssler Fiorenza \& J.P. Galvin (eds.), Systematic theology: Roman Catholic perspectives, 2 nd edn., pp. 431-460, Fortress Press, Minneapolis, MN.

Johnson, E.A., 2014, Ask the beasts: Darwin and the God of love, Bloomsbury, London.

Johnson, E.A., 2015, 'Jesus and the Cosmos: Soundings in deep Christology', in N.H. Gregersen (ed.), Incarnation: On the scope and depth of Christology, pp. 133-156, Fortress Press, Minneapolis, MN.

Kleinig, J., 1991, Valuing life, Princeton University Press, Princeton, NJ.

Kohl, M., 2001, 'Life and death', in L. Becker \& C. Becker (eds.), Encyclopedia of ethics, Routledge, New York.

Levinas, E., 2001, 'Interview with François Poirié 1986', in J. Robbins (ed.), Is it righteous to be: Interviews with Emmanuel Levinas, pp. 23-83, California University Press, Stanford, CA.

McDaniel, J.B. \& Bowman, D., 2006, Handbook of process theology, Chalice Press, St. Louis, MO.

Moltmann, J., 2000, 'Perichoresis: An old magic word for a new Trinitarian theology', in M.D. Meeks (ed.), Trinity, community, and power: Mapping trajectories in Wesleyan theology, pp. 111-125, Kingswood Books, Nashville, TN.

Moltmann, J., 2015, 'Is God incarnate in all that is?', in N.H. Gregersen (ed.), Incarnation: On the scope and depth of Christology, pp. 119-131, Fortress Press, Minneapolis, MN.

Morley, B., n.d., 'God, western concepts of God', Internet Encyclopedia of Philosophy. A Peer-Reviewed Academic Resource, viewed 15 August 2016, from http://www. iep.utm.edu/god-west/\#H1

Peacocke, A.R., 1993, Theology for a scientific age: Being and becoming - Natural, divine, and human, Fortress Press, Minneapolis, MN.

Pieper, J., 1991, In search of the sacred: Contributions to an answer, Ignatius Press, San Francisco, CA

Rahner, K., 1982, 'The unity of spirit and matter in the Christian understanding of faith', in Theological investigations, vol. 6, pp. 153-177, transl. Karl-H. \& B. Kruger, Crossroad, New York.

Ricoeur, P., 2009, Philosophie de la Volonté, t. Il: Finitude et Culpabilité, Éd. Points, Paris.

Scheler, M., 1960, On the eternal in man, transl. B. Noble, SCM Press Ltd, London.

Suchocki, M., 1982, God, Christ, Church: A practical guide to process theology, Crossroad, New York. 
Suchocki, M., 1997, 'Spirit in and through the world', in J.A. Bracken \& M. Suchock (eds.), Trinity in process: A relational theology of God, pp. 173-190, Continuum, New York.

Trethowan, I., 1985, Process theology and the Christian tradition: An essay in Post Vatican II thinking, St. Bede's Publications, Still River, MA.

Uniacke, S., 2004, 'Is life sacred?', in B. Rogers (ed.), Is nothing sacred?, pp. 59-80, Routledge, London.

Urbaniak, J. \& Otu, E., 2016, 'How to expect God's reign to come: From Jesus' through the Ecclesial to the cosmic body', HTS Teologiese Studies/Theological Studies 71(1), Art. \#3380, 1-11. http://dx.doi.org/10.4102/hts.v71i1.3380

Waaijman, K., 2002, Spirituality: Forms, foundations, methods, Dudley, MA.
Webster, J.B., 2003, Holiness, W.B. Eerdmans Pub., Grand Rapids, MI.

Welker, M., 2014, 'What is the "Spiritual Body?"', in P. Davies \& N.H. Gregersen (eds.), Information and the nature of reality: From physics to metaphysics, pp. 349-364, Cambridge University Press, Cambridge.

Wieman, H.N., 1946, The source of human hood, University of Chicago Press, Chicago, IL.

World Council of Churches, Canberra Assembly (WCC), 1991, 'Giver of life sustain your creation!', in M. Kinnamon (ed.), Signs of the spirit, Wn. B. Eerdmans, Grand Rapids, MI.

Zunic, N., 2014, 'Models of holiness', The Heythrop Journal 55(2), 256-269. http:// dx.doi.org/10.1111/j.1468-2265.2009.00511.x 